\title{
Contemporary Status of Heavy Metal Contamination in Soils Affected by Tannery Activities, Ranipet, South India
}

\section{KISTAN ANDIYAPPAN ${ }^{1 *}$, VIJAYA ANANDAN VEERASAMY ALAGARSAMY ${ }^{1}$ and THAMINUM ANSARI ABUBACKER ${ }^{2}$}

\author{
${ }^{1}$ Research and Development Centre, Bharathiar University, Coimbatore, Tamil Nadu. \\ ${ }^{2}$ Assistant Professor, P.G. Research Department of Chemistry, Muthurangam Govt. Arts College, Vellore. \\ ${ }^{*}$ Corresponding author E-mail: vishmikrish@gmail.com \\ http://dx.doi.org/10.13005/ojc/330650
}

(Received: September 05, 2017; Accepted: October 01, 2017)

\begin{abstract}
This study was focused to reveal the current heavy metal pollution in soil by tannery activities. This research was done at the site of the Tannery, Residential and normal agricultural areas in two layers of the soil samples at Ranipet, Vellore district. We evaluated only four heavy metals $(\mathrm{Cr}, \mathrm{Pb}, \mathrm{Cd}, \mathrm{Zn})$ contamination in the soil samples of study area. Flame AAS (Atomic Absorption Spectrometer) technique was used to determine these four heavy metals concentration. This result showed that heavy metals concentration is significantly higher in soil at the site of the tannery locality than in the normal agricultural and residential areas and also these four metals strength was found to be not very much significant changes in soil at the site of the normal agricultural and residential areas. These metals contamination in the soil is answerable for the support of harmfulness in farming crops and underground water.
\end{abstract}

Keywords: Heavy metal, Tannery locality, Agricultural areas, Residential zone, Ranipet.

\section{INTRODUCTION}

Now a days, human health and environment associated complication due to trace metal pollution has turn into anxiety. Heavy metal functions in the soil structure are more and more becomes problem of worldwide anxiety. Heavy metals pollution in soil disagreeably suffers its physico-chemical standards vital to sterility and minimum harvest of crops owing to its harmfulness. Present days, with growing of worldwide economic status, heavy metal contamination in soil has progressively enlarged, ensuing in the weakening of the ecosystem. Fertility of soil is diminished by heavy metals contamination through the latest irrigation methods; resulting poisonousness is received into tropical food cycle that suffers the quality of food and food protection. Soil contamination by heavy metal due to tannery effluents becoming a universal problem. Effluents coming industries, tanneries and other extra sources brings a huge amount of harmful metals such as Iron $(\mathrm{Fe}), \quad$ Manganese(Mn), Nickel(NI), Magnesium(Mg), Cobalt(Co), Arsenic(As), Chromium(Cr), Lead $(\mathrm{Pb}), \quad \operatorname{Zinc}(\mathrm{Zn})$, and Cadmium (Cd) etc. these metals are answerable for soil pollution of cultivation land ${ }^{1,6,7}$. 
Tanneries are most useful foreign money sector In India. More than 600 tanneries are located in Vellore district and among them, 150 are situated in Ranipet, Vellore district close to the Palar River, covered apart of $48 \mathrm{~h}$ and the remaining tanneries are situated in further Towns of Vellore district. Vellore district tanneries are posing a heavy risk for our surroundings. For tanning process, lots of chemical substances are used like dyes, Sodium Chloride salt, Calcium hydroxide; Chromium salt, Inorganic acids are widely handled to complete process. During tanning process only $50-60 \%$ of raw skin takes the functional chemical and remaining discharged as wastes. Almost many tanneries of Vellore district do not have sewage management conveniences. Tanneries are disposing untreated wastes and sewage straightly to open drainage which will be lastly connecting in the Palar River. They are discharged minimum 10,000 $\mathrm{Ld}^{-1}$ raw wastes $8,9,10,11$. A few workers confirmed that throughout peak stage minimum 14000 liter per day, off-peak stage minimum 9000 liter per day effluent discharged by tannery activities ${ }^{12}$. Heavy Metals substances in land might reach into the human and animal bodies straightly through skin contact, absorption, watered. Accumulation Heavy Metals in cultivation land are absorbed through vegetables and fruits etc. which is the chief way of destructing animal and human physical conditions ${ }^{13,14,15}$.

The focus of our study was current status of abundant metals $(\mathrm{Cr}, \mathrm{Pb}, \mathrm{Zn}, \mathrm{Cd})$ in and around tannery discharge affected land and compared the results with the contamination of abundant heavy metals in uncontaminated land such as agricultural and residential areas of Ranipet, Vellore district, Tamil Nadu which were not compared in the past studies ${ }^{16,17}$. This research was carried out using the Flame atomic absorption spectrometer to estimate the amount of $\mathrm{Zn}, \mathrm{Cr}, \mathrm{Pb}$, and $\mathrm{Cd}$. "Varian Spectra A240" Model-Flame atomic absorption spectrometer was used in this research which was very simple operating spectrometer, less time required to do experiments, can get precision results, easy to handled, and can be used to estimate other heavy metals also. From this research it has been explained that heavy metals contagion in soil has now a day's become a major concern. In a growing nation of India, the condition is not better because of deficient of scientific improvement. It is clearly evident that tanneries locality soil samples of Ranipet, Vellore district is moderately to extremely contaminated with $\mathrm{Cr}$, whereas $\mathrm{Cd}, \mathrm{Pb}$ and $\mathrm{Zn}$ are very slightly to uncontaminated. These problems are owing to being exposed to a large quantity of unprocessed wastes released from tanneries day by day. This kind of metal contamination can be suppressed by using some low cost adsorbent which are easily available such as coconut shell, rice husk carbon, fly-ash, charcoal etc. before discharging effluent into surface water body these adsorbent should be used in order to suppress metal contamination.

\section{MATERIALS AND METHODS}

\section{Study area}

Ranipet is a one of the industrialized division of Vellore District in Tamil Nadu and situated in $79^{\circ} 192-79^{\circ} 222$ East longitude and $12^{\circ} 532-12^{\circ} 572$ North latitude and its $93 \mathrm{Km}$ west of Chennai (Capital of Tamil Nadu state in India). Ranipet is geologically $26 \mathrm{Km}$ away from the North East of central Vellore city, Tamil Nadu. In Ranipet has SIDCO \& SIPCOT to set up the estates, because it is located at a gap of $3 \mathrm{Km}$ from River Palar and bordering Chennai to Bangalore Road $(\mathrm{NH}-4)$ via Chittoor. Ranipet is continual contaminated region. It is also the largest distributing center of tanning leather products. A lot of tiny-sized tanneries are handling leather in this area and releasing of wastes on the open land and adjoining watery regions like lake, pond and river. Many tanneries are positioned in and around this Ranipet town, in addition ceramic industries, refractory industries, dye industries, and chromium chemicals industries are situated in Ranipet. These industries are releasing wastes into lakes which are situated in Vanapadi, Puliathengal, and Thandalam and it is a subject of becoming larger concern, as above industrial unites are situated near $P$ alar river region. Studies of groundwater also specified the highest concentrations of chromium in Palar river region, which is more than the acceptable limit in consumption water. These tanneries are also contaminating the Palar River region, causing environmental deterioration and physical and mental health problems ${ }^{18,19}$.

\section{Geology of study area}

Geologically the research region is surrounded by crystal-like rocks of Achaean age containing of granites and a few essential intrusive 
bodies. The alluvium containing of small to big size sand with clay occurring in the region is of a fluviatile source and controlled to the passage of Palar River and most important rivers ${ }^{20}$.

Analysis of the sample was completed by Atomic Absorption Spectroscopy. In this method, the photo energy due to exact wavelength gets absorbed while the electrons of the constituent metals of the sample gains energy from a lower to a higher energy level. The intensity of light passing through the sample is compared with that of the standard solutions of the element to be estimated. Their corresponding absorbance is measured and their concentration is calculated through calibration curves plotted with concentration against absorbance values (Beer-Lambert's law).
Seven soil samples (Fig.1) were collected from seven various points in the tannery region, agricultural area and residential zone where densely populated area in Ranipet, Vellore district. There are many registered tannery plants release their vast quantity of unprocessed liquid and solid wastes straightly in the Palar River bodies and other water bodies. Hence Ranipet was chosen as a study zone to relate the level of heavy metal contamination with other non-tannery areas. Four dissimilar points near tannery locality were labeled as TA-1(discarding point itself) TA-2, TA-3, TA-4, TA-5, TA-6, TA-7 which are located at 0-50 m, 100-200 m, 250-300 m, 400$500 \mathrm{~m}, 550-600 \mathrm{~m}, 750-850 \mathrm{~m}$ and $1000-1200 \mathrm{~m}$ distance correspondingly from the discarding area. Agricultural area and Residential areas were labeled as $A A$ and $R A$ respectively.

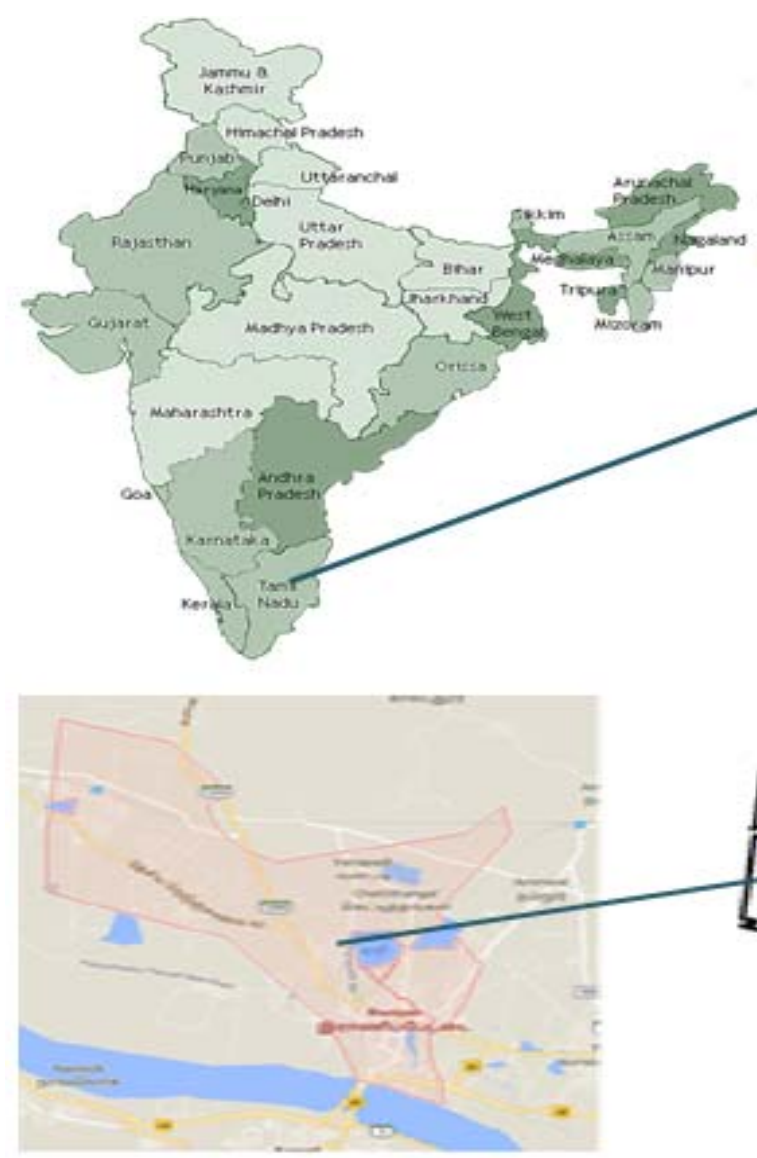

Tannery locality
Residential zone $\triangle$
Ranipet

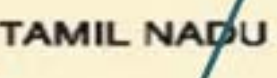

TAMIL NADU

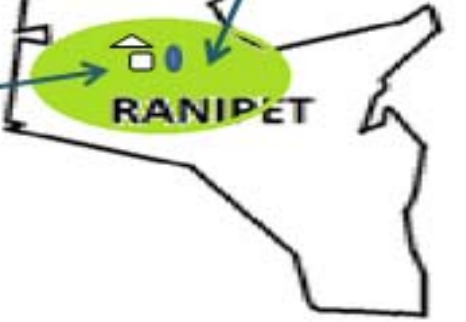

Agricultural are.

Fig.1. Geographical map of Study area 


\section{Sampling period}

In the month of May 2017, the soil samples were collected from the sampling sites with the help of a Steel Trenching hoe and transferred to pre cleaned plastic bottles. The samples were collected from twodissimilar layers of different depth at all point. The first layer is the shallow layer $(0-10 \mathrm{~cm})$ and the other is $30-40 \mathrm{~cm}$ below from the surface level by measuring with $100 \mathrm{~cm}$ wood ruler. After gathering the soil samples were washed, weighed and dried in an oven at $110^{\circ} \mathrm{C}$ until become constant weight. After cooling in desiccators with fused Calcium chloride all the samples were crushed and thoroughly homogenized by manually with help of stone soil grinder. The crushed soil samples were lastly stored in cleaned dry closed glass bottles and well-maintained in desiccators for further analysis.

\section{Digestion of Soil Sample}

For the quantitative analysis of $\mathrm{Cr}, \mathrm{Pb}, \mathrm{Cd}$ and $\mathrm{Zn}$ soil samples were digested following ISO 11466 thermal heating methods. According to this method, first $5 \mathrm{~g}$ of each crushedsoil samples were weighed and taken into pre cleaned $100 \mathrm{ml}$ glass beakers. Then the weighed samples were humidified with $2 \mathrm{ml}$ of deionized water. After that $24 \mathrm{ml}$, of $\mathrm{HCl}$ and $8 \mathrm{ml}$ of $\mathrm{HNO} 3$ were poured drop by drop and then $18 \mathrm{ml}$ of dilute $\mathrm{HNO}(0.5 \mathrm{M})$ was poured to every beakers and the samples were permitted to position at lab temperature (27-300C). Every mixture was then refluxed on a heating not plate for $2 \mathrm{hrs}$ and was filtered through filter paper (Whitman no 42) after cooling and kept at room temperature for further analysis.

\section{Total heavy metals concentration measurement} The digested soil substances used for determination of Chromium, Lead, Cadmium and Zinc by using Flame atomic absorption spectrometer ( FAAS - Model Varian Spectra A240), (Sample volume - $10 \mathrm{~mL} / \mathrm{min}$. Burner - Air/ Acetylene, $\mathrm{N}_{2} \mathrm{O}$ /Acetylene burner/Gases hallow cathode - Acetylene and nitrous oxide) at Technology Business incubator Lab, Department of Science and Technology, VIT-university, Vellore, Tamil Nadu. Cd $\left(\lambda_{\text {max }}: 228.8 \mathrm{~nm}\right), \operatorname{Cr}\left(\lambda_{\max }: 357.9 \mathrm{~nm}\right), \mathrm{Pb}$ $\left(\lambda_{\max }: 283.3 \mathrm{~nm}\right)$, and $\mathrm{Zn}\left(\lambda_{\max }: 213.9 \mathrm{~nm}\right)$ exact hollow cathode lamp was used to analyze the samples. The instrument having a minimum detection limit of $0.01 \mathrm{mg} / \mathrm{L}$ for $\mathrm{Cd}, 0.10 \mathrm{mg} / \mathrm{L}$ for $\mathrm{Cr}$, $0.20 \mathrm{mg} / \mathrm{L}$ for $\mathrm{Pb}$ and $0.01 \mathrm{mg} / \mathrm{L}$ for $\mathrm{Zn}$ in the flame method. Substances were aspirated over Nebulizer and absorbance was measured with a colorless solution (Deionized water) as reference. Calibration curve was obtained using know concentration samples (containing 0.1, 0.2, 0.3, 0.4, 0.5,. 06, 0.7, $0.8 \mathrm{mg} / \mathrm{L}$ for $\mathrm{Cd}$; $0.4,0.8,1.2,1.6$ and $2.0 \mathrm{mg} / \mathrm{L}$ for $\mathrm{Cr} ; 0.2,0.4,0.6,0.8$ and $1.0 \mathrm{mg} / \mathrm{L}$ for $\mathrm{Pb}$ and 0.5 , $1.0,1.5,2.0,2.5$ and $3.0 \mathrm{mg} / \mathrm{L}$ for $\mathrm{Zn}$ ).

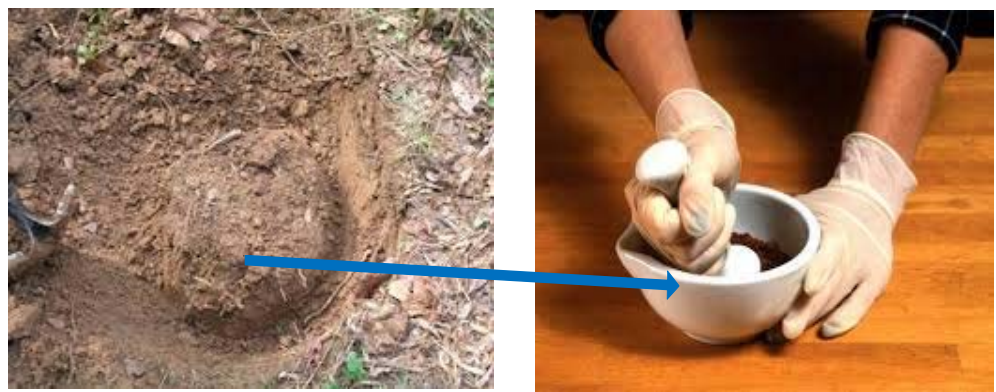

Fig. 2. Soil samples preparation
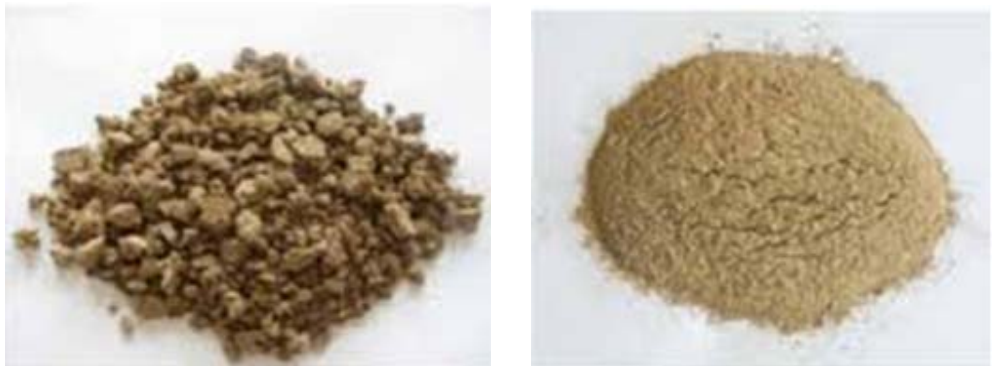

Soil samples

Fig.3: Prepared Soil Samples 
Table. 1: Heavy metal analysis of tannery locality soil samples

\begin{tabular}{|c|c|c|c|c|c|c|}
\hline $\begin{array}{l}\text { Sampling } \\
\text { places }\end{array}$ & $\begin{array}{l}\text { Distance from dumping } \\
\text { of tannery wastes }(\mathrm{m})\end{array}$ & $\begin{array}{l}\text { Depth of layers } \\
\text { from superficial } \\
\text { level }(\mathrm{cm})\end{array}$ & $\begin{array}{c}\mathrm{Cr} \\
\left(\mathrm{mgKg}^{-1}\right)\end{array}$ & $\begin{array}{c}\mathrm{Pb} \\
\left(\mathrm{mgKg}^{-1}\right)\end{array}$ & $\begin{array}{c}\mathrm{Cd} \\
\left(\mathrm{mgKg}^{-1}\right)\end{array}$ & $\begin{array}{c}\mathrm{Zn} \\
\left(\mathrm{mgKg}^{-1}\right)\end{array}$ \\
\hline \multirow[t]{2}{*}{ TA-1 } & $0-50$ & $0-10$ & 1524.28 & 92.58 & 5.86 & 282.32 \\
\hline & & $30-40$ & 584.64 & 76.61 & 2.16 & 124.24 \\
\hline \multirow[t]{2}{*}{ TA-2 } & $100-200$ & $0-10$ & 1088.26 & 64.23 & 4.20 & 187.31 \\
\hline & & $30-40$ & 236.29 & 60.42 & 1.92 & 97.40 \\
\hline \multirow[t]{2}{*}{ TA-3 } & $250-300$ & $0-10$ & 590.68 & 42.29 & 2.82 & 173.5 \\
\hline & & $30-40$ & 208.70 & 26.50 & 1.60 & 65.39 \\
\hline \multirow[t]{2}{*}{ TA-4 } & $400-500$ & $0-10$ & 432.11 & 38.73 & 2.02 & 107.23 \\
\hline & & $30-40$ & 133.33 & 20.37 & 1.15 & 63.05 \\
\hline \multirow[t]{2}{*}{ TA-5 } & $550-600$ & $0-10$ & 270.84 & 28.45 & 1.85 & 120.52 \\
\hline & & $30-40$ & 101.43 & 20.06 & 1.04 & 85.69 \\
\hline \multirow[t]{2}{*}{ TA-6 } & $750-850$ & $0-10$ & 256.61 & 15.68 & 1.82 & 72.36 \\
\hline & & $30-40$ & 98.26 & 5.68 & 1.06 & 46.48 \\
\hline \multirow[t]{7}{*}{ TA-7 } & $1000-1200$ & $0-10$ & 110.47 & 16.08 & 1.87 & 55.59 \\
\hline & & $30-40$ & 59.45 & 5.28 & 0.66 & 47.46 \\
\hline & MaximumMinimum & & 1524.28 & 92.58 & 5.86 & 282.32 \\
\hline & MeanStandard deviation & & 59.45 & 5.28 & 0.66 & 46.48 \\
\hline & (SD)Maximum allowable & & 406.81 & 36.64 & 2.04 & 109.18 \\
\hline & limitrecommended by EC $(1986)^{13}$ & & 410.59 & 26.19 & 1.025 & 63.96 \\
\hline & & & 50 & 300 & 3 & - \\
\hline
\end{tabular}

Table. 2: Heavy metal analysis of agricultural soil samples

\begin{tabular}{lccccc}
\hline $\begin{array}{l}\text { Sampling } \\
\text { places }\end{array}$ & $\begin{array}{c}\text { Depth of layers from } \\
\text { superficial level }(\mathrm{cm})\end{array}$ & $\mathrm{Cr}\left(\mathrm{mgKg}^{-1}\right)$ & $\mathrm{Pb}\left(\mathrm{mgKg}^{-1}\right)$ & $\mathrm{Cd}\left(\mathrm{mgKg}^{-1}\right)$ & $\mathrm{Zn}\left(\mathrm{mgKg}^{-1}\right)$ \\
\hline $\mathrm{AA}$ & $0-10$ & 79.71 & 31.14 & 2.46 & 48.23 \\
& $30-40$ & 51.09 & 26.61 & 2.28 & 40.73 \\
& Mean & 50.90 & 28.87 & 2.37 & 44.48 \\
& Standard deviation (SD) & 10.80 & 2.26 & 0.09 & 3.75 \\
& Maximum allowable limit & 50 & 300 & 3 & - \\
\hline
\end{tabular}

Table. 3: Heavy metal analysis of Residential Zone soil samples

\begin{tabular}{|c|c|c|c|c|c|}
\hline $\begin{array}{l}\text { Sampling } \\
\text { places }\end{array}$ & $\begin{array}{l}\text { Depth of layers from } \\
\text { superficial level }(\mathrm{cm})\end{array}$ & $\mathrm{Cr}\left(\mathrm{mgKg}^{-1}\right)$ & $\mathrm{Pb}\left(\mathrm{mgKg}^{-1}\right)$ & $\mathrm{Cd}\left(\mathrm{mgKg}^{-1}\right)$ & $\mathrm{Zn}\left(\mathrm{mgKg}^{-1}\right)$ \\
\hline \multirow[t]{3}{*}{ RA } & $0-10$ & 41.71 & 50.58 & 2.05 & 18.33 \\
\hline & $30-40$ & 30.10 & 26.60 & 1.08 & 15.56 \\
\hline & Mean & 35.65 & 38.29 & 0.48 & 16.94 \\
\hline \multicolumn{2}{|c|}{ Standard deviation (SD)9.80 } & 11.98 & 1.56 & 1.38 & \\
\hline \multicolumn{2}{|c|}{$\begin{array}{l}\text { Maximum allowable limit } \\
\text { recommended by EC }(1986)^{13}\end{array}$} & 50 & 300 & 3 & - \\
\hline
\end{tabular}




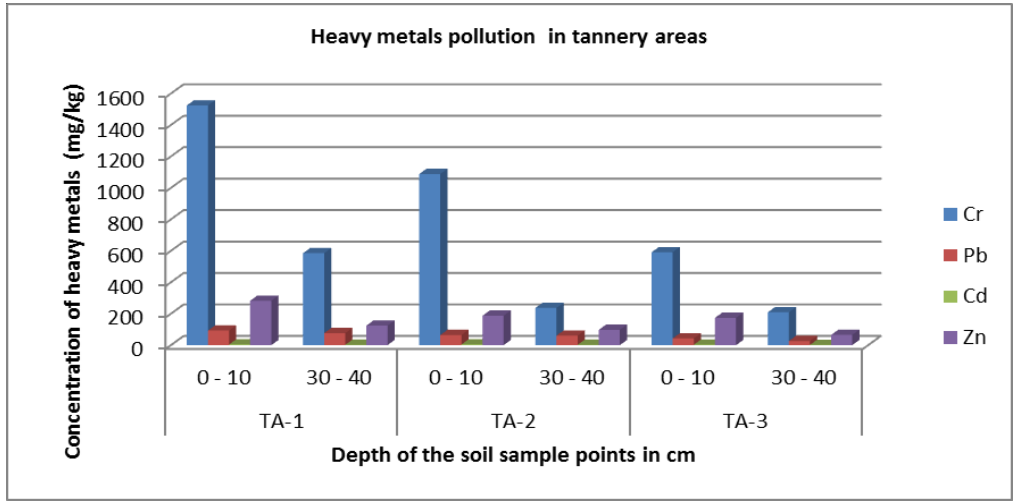

Fig. 4. Heavy metals in tannery locality soil samples

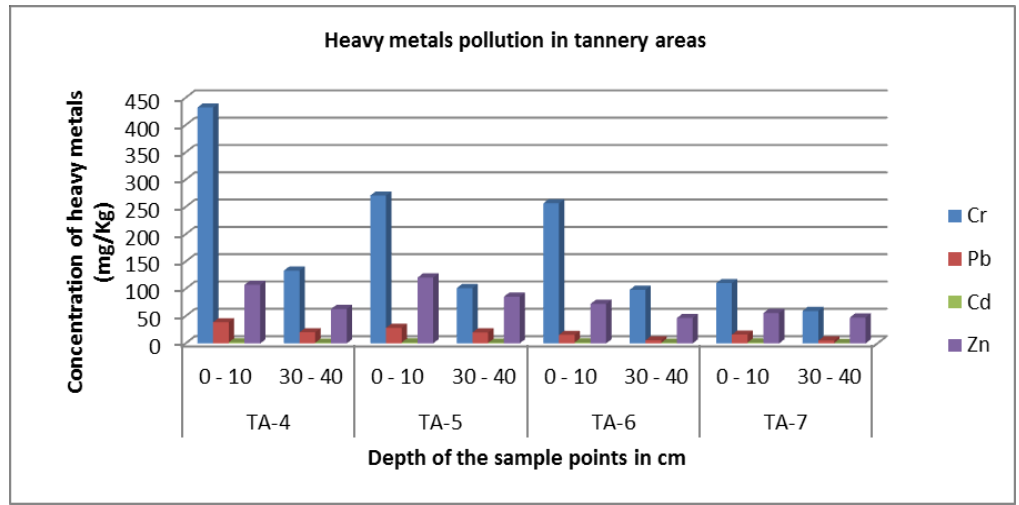

Fig.5. Heavy metals in tannery locality soil samples

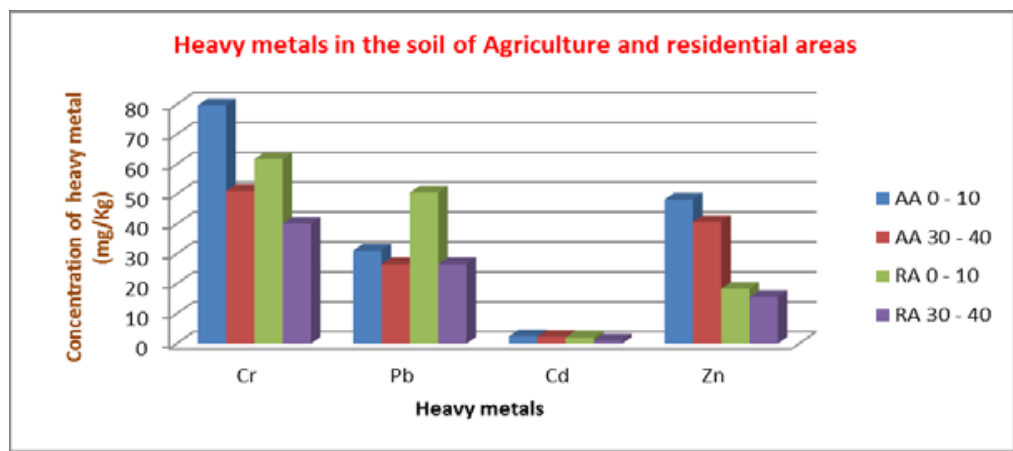

Fig.6. Heavy metal in Agriculture and Residential areas soil

\section{RESULT AND DISCUSSION}

After this survey, it is cleared that contamination by chromium in the locality of tannery is honestly higher in all seven tannery location samples and observed that $\mathrm{Cr}$ was exceeded the permissible limits (Table.1). The outcome verified maximum concentration of heavy metals at the tannery effluent discharging zone and minimum concentration in the soil of Agriculture area and residential zone. These heavy metals concentration was found maximum abundantly in the superficial layers of the soil and the concentration of heavy metals reduced with the increase of depth and distance (Table. 1, 2\& 3 and Fig. 4 \& 5). It is accepted that in the place of Tannery zone soil samples, $\mathrm{Cr}$ content was found more quantity $\left(1524.28 \mathrm{mgKg}^{-1}\right)$ in 0-10 cm depth (surface layer) of TA-1 (effluent discharging point) and least abundant (59.45 $\left.\mathrm{mgKg}^{-1}\right)$ in 30-40 cm depth of TA-7. In the superficial layer of 
soil samples, the values for $\mathrm{Cr}$ concentration changed from 1524.28 to $110.47 \mathrm{mgKg}^{-1}$, in $0-10$ $\mathrm{cm}$ depth, it ranged from 584.64 to $59.45 \mathrm{mgKg}^{-1}$ in 30-40 cm depth ( Table.1). The case of Agricultural and residential areas soil, $\mathrm{Cr}$ content in surface layer, $0-10 \mathrm{~cm}$ and $30-40 \mathrm{~cm}$ depth is found 79.71 - 51.09 ( Table.2) And 41.71, - $30.10 \mathrm{mgKg}^{-1}$ (Table.3) Correspondingly.

From this end report, it is obvious that Chromium in the Tannery surrounding area of same layers reduced with increased of distance from the tannery effluent discharging place and also with the increased of deepness in sample places (Fig. 4 \& 5). In the superficial soil layer $(0-10 \mathrm{~cm})$, the rate of reducing $\mathrm{Cr}$ concentration with distance was higher than depth deposits of 30-40 cm (Fig.4, 5\& 6). In all cases $\mathrm{Cr}$ contamination in the tannery location soil samples were found higher than agricultural and residential areas soil samples (Fig. 4, 5 \& 6). In Tannery surrounding area, in the superficial deposit of each sample place, chromium concentration was exceeded the permissible limit of $50 \mathrm{mgKg}^{-1}$ (Table. 1$)^{21}$. But Agricultural Area soil slightly exceeded and Residential soil samples did not exceed that limit (Table. 2 \& 3). The excess concentration of chromium in the superficial layer of tannery surrounding area soil samples might be due to pollution from different industrial wastes such as chromium-pigment and raw solid wastes from tannery, leather industrialized wastes, and municipal sewage mud etc. ${ }^{22}$ Chromium present in the soil owing to waste with Lead-Chromium batteries, colored plastic bags, surplus plastic tools and unfilled paint bottles ${ }^{23}$. Chromium is poisonous and cancer-causing and long-standing contact to chromium may cause kidney problems and liver impairment ${ }^{24}$. Chromium could also modify hereditary materials and cause for cancer. Additional health troubles are Skin diseases, stomachs upset, respiratory problems, ulcers problems, damaged immune body systems, change of hereditary material, respiratory disease and death that area used by chromium ${ }^{25}$.

Lead is the next common metal in this study. In the case of Tannery surrounding area, Lead content was found more abundant $\left(92.58 \mathrm{mgKg}^{-1}\right)$ in the superficial layer of point TA-1 (waste discharging point) and minimum quantity abundant $\left(5.28 \mathrm{mgKg}^{-1}\right)$ in the depth layer(30-40 $\mathrm{cm})$ of point TA-7. In the superficial layers $(0-10 \mathrm{~cm})$, the concentration of $\mathrm{Pb}$ ranged from 92.58 to $16.08 \mathrm{mg} /$ $\mathrm{Kg}$, whereas in the depth layer $(30-40 \mathrm{~cm})$ of soil, $\mathrm{Pb}$ concentration varied from 76.61 to $5.28 \mathrm{mg} / \mathrm{Kg}$ (Table.1\& Fig.4,5). While in the case of Agricultural and Residential area soil, $\mathrm{Pb}$ content in the superficial layer $(0-10 \mathrm{~cm})$ and depth layer $(30-40 \mathrm{~cm})$ was found $31.14-26.61 \mathrm{mgKg}^{-1}$ and $30.58-16.61 \mathrm{mgKg}^{-1}$ respectively (Table. $2 \& 3$ ). Also $\mathrm{Pb}$ content in the Tannery surrounding area soil of similar layers, the values decreased with the increase of distance from the dumping spot and also with the increase of depth at each point. In the superficial layer $(0-10 \mathrm{~cm})$, the rate of $\mathrm{Pb}$ contamination decreased with distance but higher than other layers of $30-40 \mathrm{~cm}$ depth (Fig. 4\&5). Neither Tannery surrounding area soil nor Agricultural Area soil at any layer in this study exceeded the allowable limit for $\mathrm{Pb}$ that is $300 \mathrm{mgKg}^{-1} 26$. The high content of $\mathrm{Pb}$ content near the discarding point may be due to the discharge of $\mathrm{Pb}$-containing untreated tannery effluent.

The presence of $\mathrm{Pd}$ in soil can happen due to the release of $\mathrm{Pb}$ by automobiles using leaded petrol and other industries in this study area. This $\mathrm{Pb}$ content may be deposited on top soil and water, thus reaching humans by way of the food chain. $\mathrm{Pb}$ in the soils might also be from vehicle exhaust smoke as well as dry cell batteries, sewage effluents, runoff of wastes and atmospheric depositions ${ }^{27}$. Pb exposure has effects like disruption of the biosynthesis of red blood cell in blood and anemia, miscarriages, kidney damage, and subtle abortions, disruption of nervous methods, enhance in blood pressure, Brain grievance, declined fertility of men through sperm impairment, decreased schooling abilities of children, Behavioral disruptions of kids, such as aggression, hyperactivity and imprudent behaviour ${ }^{28}$.

Cadmium pollution in soil was also determined in this study; more abundant Cd (5.86 $\mathrm{mgKg}^{-1}$ ) was found in the top soil layer of TA-1 (discharging point) and smallest amount (0.71 $\mathrm{mgKg}^{-1}$ ) found in deep layer of $30-40 \mathrm{~cm}$ soil depth of TA-7 in the region of Tannery locality. In superficial layers $(0-10 \mathrm{~cm}) \mathrm{Cd}$ concentration was varied from 2.46 to $1.87 \mathrm{mgKg}^{-1}$, while in the deep layer of soil $(30-40 \mathrm{~cm}) \mathrm{Cd}$ concentration range was from 2.16 to $0.66 \mathrm{mgKg}^{-1}$ (Table. 1). Whereas in the case of agricultural and residential areas soil, $\mathrm{Cd}$ 
concentration in superficial layer $(0-10 \mathrm{~cm})$ and depth layer $(30-40 \mathrm{~cm}$ ) was found $2.46-2.28 \mathrm{mgKg}$ ${ }^{1}$ and $3.05-1.08 \mathrm{mg} \mathrm{Kg}^{-1}$ respectively (Table 3 \& 4). At the sample TA-4, TA-5, TA-6 and TA-7. In the superficial soil layers $(0-10 \mathrm{~cm})$ of tannery area $\mathrm{Cd}$ contamination was decreases with increases of distance from the disposal point (Fig. 4\&5). Cd also decreased with the increase of depth at all points in the tannery locality like $\mathrm{Cr}$ and $\mathrm{Pb}$ (Fig. 4\&5). Other than this was not the case for agriculture and residential areas soil samples. In superficial layers, Cd concentration in all sample point of the Tannery surrounding area was estimated slightly high compared to Agricultural and residential areas (Table. 1, 2 \& 3). But not similar to $\mathrm{Cr}$ and $\mathrm{Pb}, \mathrm{Cd}$ concentration in depth layers $(30-40 \mathrm{~cm})$ of Agricultural and residential areas soil was found slightly lower than that of each point in the Tannery vicinity soil (Fig. 4, 5 \& 6). In all layers of Tannery region, Agricultural and residential areas soil samples, $\mathrm{Cd}$ concentration was not exceeded than maximum acceptable limit (3.0 $\left.\mathrm{mgKg}^{-1}\right)$ (Table 1, 2\& 3). The $\mathrm{Cd}$ was bringing the soil by the use of phosphoric manures. Use of excess of phosphate and phosphate compound manures increases $\mathrm{Cd}$ content in soil continuously. Other sources of $\mathrm{Cd}$ content might be ceramics, paint, plastics and glass production industries. The $\mathrm{Cd}$ is extremely toxic and even at very small amount; chronic contact to this metal can major to anemia, insomnia, cardiovascular problems, hyper-tension etc. ${ }^{1,29,30}$.

Likewise for Zinc, In Tannery locality highest concentration $(282.32 \mathrm{mg} / \mathrm{Kg})$ of $\mathrm{Zn}$ was estimated in the superficial layer $(0-10 \mathrm{~cm})$ of sample point TA-1 (waste discharging point) and minimum abundant $\left(46.48 \mathrm{mgKg}^{-1}\right)$ in the depth layer $(30-40 \mathrm{~cm})$ of at the sample point of TA-7 (Table.1). In superficial deposit of soil $(0-10 \mathrm{~cm})$, range of $\mathrm{Zn}$ concentration was from 282.32 to 55.59 $\mathrm{mg} \mathrm{Kg}^{-1}$, in the layer of $30-40 \mathrm{~cm}$ depth, the $\mathrm{Zn}$ concentration varied from 124.24 to $46.48 \mathrm{mgKg}^{-1}$ (Table 1 \& Fig. 4, 5). Whereas in the cases of residential and agriculture area soil samples, Zinc concentration in the upper most layer, $(0-10 \mathrm{~cm})$ and $30-40 \mathrm{~cm}$ depth layer was estimated 48.23$40.73 \mathrm{mgKg}^{-1}$ and $18.33-15.56 \mathrm{mgKg}^{-1}$ correspondingly (Table. 2, 3 \& Figure. 6).

It is also noticed that in the case of the superficial layers $(0-10 \mathrm{~cm})$ and depth layers $(30-40 \mathrm{~cm})$ of Agricultural Area and residential areas soil possess lower Zn concentration than Tannery locality soil samples at each point (Table. 1,2\&3).

The major origin of zinc pollution is use of liquid fertilizers and pesticides in cultivation land, industrial activities. This is due zinc is necessary trace metal for the growth of plants, for human and animal metabolism other than is potentially hazardous for the earth planet when it is abundant in more concentrations. But high dose of zinc content leads to carcinogenic effects, poisonous, neurological problems, hypertension, kidney and liver problems ${ }^{1,31}$.

\section{CONCLUSION}

Now a day's contamination of land becoming a most important responsibility. In growing country of India, the condition is most horrible because of inadequate scientific improvement. In this revise, it is proved that the soil samples in the tannery locality of Ranipet, Vellore district is exceedingly contaminated with $\mathrm{Cr}$ not with other $\mathrm{Pb}, \mathrm{Cd}$ and Zinc. This is as a result of being acquired an enormous quantity of raw tanning process wastes coming from the near Tanneries day after day.

This study reported that these four heavy metals concentration is significantly higher in soil at the site of the tannery locality than in the normal agricultural and residential areas and also these four metals strength was found to be not very much significant changes in soil at the site of the normal agricultural and residential areas. A considerable quantity of Cadmium, Zinc and Lead has also been found in the soil of this area which were not exceedingly contaminated but very slightly contaminated in only few sample points in this study locality. These kind of metals might accumulated in soil and adsorbed by vegetables and fruits through route of plants and some other crop grown-up in this study area that eventually gets into human and animals through the tropical food cycle. These reports at different unpleasant effects for human physical condition as chromium, lead and cadmium are extremely poisonous and cancer causing agent in the environment. So governments need to take instantaneous measures for these problems to control this kind of infectivity by heavy metal contamination. 


\section{Remedy}

In order to overcome the above problems, heavy metal can be suppressed from effluents and waste of tanneries and other industries, some low cost adsorbent can be recommended such as coconut shell carbon, rice husk carbon, fly-ash, charcoal etc. before discharging effluent into surface water body these adsorbent should be used which will be very useful to suppress metal contamination.

\section{REFERENCES}

1. Rahaman, A.; Afroze, J.S.; Bashar,K., Ali, M.F; Hosen, M.R. American Journal of Analytical Chem. 2016, 7(12), 880.

2. Shaari, H.; Mohd,M.S.; Abdullah,N.A.; Bidai, J. Orient. J. Chem., 2015, 31(2), 993-999.

3. Syrlybekkyzy, s.; suleimenova, n.; zhardemovich, g.; nurbayeva,f.; permyakov, v. Orient. J. chem. 2014, 30(4), pp.1631-1638.

4. del MOar López, T.; Aide, T.M. ; Thomlinson, J.R. A Journal of the Human Environ. 2001, 30, 49-54.

5. Maria, L.R.; Lauro, F.V.; Marcela, R.N.; Del Socorro, H.M.M.; Catalina, C.O. and Francisco, D.C. Orient. J. Chem. 2017, 33(3), 1061-1070.

6. Bollikolla, H.; Pulapaka, S.; Avuguddi, R.B.; Dasaripalli, J.R.; Arza, V.S. Orient. J. Chem. 2016, 32(4), 2275-2282.

7. Su, C,; Jiang, L.; Zhang; W. Environ. Skepticsand Critics. 2014, 3, 24-38.

8. G. Mohan, D. and Pittman, C.U. Journal of hazardous materials. 2006, 137(2), 762-811.

9. Subramanian, K.S. ;Selvan, T.A. GSI Publications, 2001, 2(1).

10. Muchuweti, M.; Birkett, J.W.; Chinyanga, E.; Zvauya, R.; Scrimshaw, M.D.; Lester, J.N. Agriculture, Ecosystems \& En-vironment. 2006, 112, 41-48.

11. E.Ong, M.C.; Menier, D.; Shazili, N.A.M.; Kamaruzzaman, B.Y. Orient. J. Chem. 2013, 29(1), 39-45.

12. F.Anda, M. Geoderma. 2012, 189, 388-396.

13. Huq, S.I. Aciar Proceedings, Coimbatore. 1998, 31 January-4 February 1998.

14. Afzal, M.; Shabir, G.; Iqbal, S.; Mustafa, T.; Khan, Q.M.; Khalid, Z.M. CLEAN—Soil, Air, Water. 2014, 42, 1133-1139.

15. I.metalsGivianrad, M.H.; Hashemi, A. Orient. J. Chem. 2014, 30(2), 737-743.
16. Chowdhury, M.; Mostafa, , M.G.; Biswas, T.K.; Saha, A.K. Water Resources and Industry. 2013, 3,11-22.

17. J .Singh, R. Orient. J .Chem. 2014, 30(1), 229-232.

18. Krishna, A.K.; Govil, P.K. Environ. Geology. 2004, 47(1), 38-44.

19. Thangarajan, M. Environ. Geology. 1999, 38(3), 209-222.

20. Arora, M.; Kiran, B.; Rani, S.; Rani, A.; Kaur, B.; Mittal, N. Food Chemistry. 2008, 111, 811-815.

21. Aelion, C.M.; Davis, H.T.; McDermott, S.; Lawson, A.B. Scie. Total Environment. 2008, 402, 149-156.

22. K.Alshammary, S.F.; Al-Horayess, O.S. 2014. Orient. J. Chem. 2014, 29(4), 1515-1522.

23. Council Directive .Offic. J. Eur. Comm. 1986, 181, 0006-0012.

24. Jung, C.; Matsuto, T.; Tanaka, N. Waste Management. 2006, 26, 1337-1348.

25. Mondol, M.; Chamon, A.S.; Faiz, B.; Elahi, S.F. Journal of Bangladesh Academy of Scie. 2011, 35, 19-41.

26. Korotkova, T.G.; Ksandopulo, S.J.; Bushumov, S.A.; Burlaka, S.D.; Say, Y.V. Orient. J. Chem. 2017, 33(1), 186-198.

27. Järup, L. British Medical Bulletin. 2003, 68, 167-182.

28. Adaikpoh, E.O. J. Environ. Earth Sci. 2013, 3, 45-54.

29. Sharma, R.; Agrawal, M.; Marshall, F. Bulletin of Environ. Contamination and Toxicology. 2006, 77, 312-318.

30. Rao, M.; Gopalkrishnan, R.; Venkatesh, B. National Symposium on Role of Earth Sciences, Lucknow, 2001, 2-4, 2001.

31. Aelion, C.M.; Davis, H.T.; McDermott, S.; Lawson, A.B. Science of the Total Environ. 2008, 402, 149-156. 